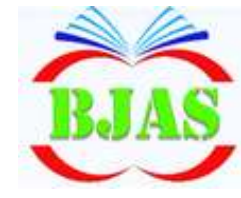

ISSN $1814-5868$
Available online at http://bjas.bajas.edu.iq

https://doi.org/10.37077/25200860.2021.34.2.09

College of Agriculture, University of Basrah
Basrah Journal

of Agricultural

Sciences

E-ISSN: 2520-0860

\title{
Relationship of some metabolic Hormones with Increased Live Body Weight of Male and Female of Karakul and Awassi Lambs
}

\author{
Thamer R. S. Aljubouri ${ }^{1}$, Firas M. Al-Khafaji ${ }^{1}$, \& Mohammed Baqur S. Al-Shuhaib ${ }^{{ }^{*}}$ \\ ${ }^{1}$ Department of Animal Production, College of Agriculture, Al-Qasim Green University, \\ Al-Qasim, Babil 51001, Iraq. \\ *Corresponding author: mohammed79@agre.uoqasim.edu.iq \\ Received 17 March 2021; Accepted 26 May 2021; Available online 3 November 2021
}

\begin{abstract}
This study was conducted in the animal field of the Al-Kafeel Company from November 2019 till May 2020 to investigate the possible association between growth hormone $(\mathrm{GH})$ and thyroxine (T4) with the growth traits in Awassi and Karakul sheep. The total number of animals which used in the study was 60 lambs, 28 (13 males and 15 females) from Karakul and 32 (18 males and 14 females) from Awassi. Blood samples were collected at birth, weaning, and six months of age, and both GH and T4 concentrations were measured. Results showed higher values of T4 for Karakul as compared with Awassi at birth and weaning. Karakul breed was also exhibited significantly higher values of GH over Awassi breed only at weaning, while, no significant differences were observed at birth and six months of age. Karakul lambs showed higher weights as compared with Awassi lambs at all studied periods. A highly significant $(p<0.01)$ positive correlation was observed between T4 concentration and the weight of lambs at most studied periods. Whereas, GH did not exhibit any correlation with growth traits measured in both breeds. The elevated T4 might be one of the reasons for superiority of Karakul over Awassi breed in live body weights. This high correlation between $\mathrm{T} 4$ and growth traits could be used in the early selection of lambs to improve the weights of sheep at marketing.
\end{abstract}

Keywords: Growth hormone, Growth traits, Sheep, Thyroxine Hormone, weight improvement

\section{Introduction}

The functions of the thyroid gland and its secreted hormones in small ruminants are essential to maintain the productive performance in sheep, such as growth, milk, and wool production. The circulating thyroxine (T4) and growth hormone (GH) can be considered as key indicators of metabolic activity, nutritional status, and livestock production (Todini et al., 2007; Oberbauer, 2015). It is well known that both $\mathrm{T} 4$ and $\mathrm{GH}$ have taken variable roles in regulating the balance of energy and protein metabolism, thermoregulation, and growth parameters in various tissues (Lopez-Rodriguez et al., 2020). Sheep breeding has great economic importance in the Middle East in such a way sheep industry has become the main source of income for breeders in these regions. However, the growth of lambs is affected by many factors, including genetic factors, the birth season, the age of 
dams, the sequence of birth, the sex of lambs and the weaning period (Jawasreh et al., 2019). Improving sheep's growth traits is the main concern of many researchers, and growth trait is the most important economic factor in animals, which is controlled by several genes (Aljubouri et al., 2020b; Imran et al., 2021). One of the most prevalent sheep breeds in Iraq is Awassi, with $58.2 \%$ of prevalence over other breeds, such as Arabi (21.8\%) and Karadi (20\%) (Aljubouri \& Al-Shuhaib, 2021). In addition, the Awassi sheep have the ability to survive and breed in conditions of drought and extreme climatic fluctuations (Al-Thuwaini et al., 2020). Although Awassi sheep have a fat tail and fleece characteristics suitable for carpet, they have slower growth, lower fertility, and lower milk production than the other surrounding breeds in the region, such as Karakul and Assaf (Halil \& Özbeyaz, 2020; Almahdawi \& Altalib, 2020). However, Awassi sheep is a genetic wealth of great importance in the sheep industry in more than 30 countries in the Middle East as well as around the world (Al-Shuhaib et al., 2019). Improving the productive performance of Awassi sheep under traditional breeding conditions faces difficulties resulting from nutrition deficiency due to the lower natural pastures, the spread of diseases, and exposure to heat stress conditions resulting from high or low temperatures (Ajam et al., 2019).

The Karakul sheep is a middle-sized and chunky tail sheep that has been dominated in the majority of Iranian regions. This breed is being widely distributed in many other Asian countries. This breed is highly resistant to harsh environmental conditions and can be raised to produce milk, meat, and fiber (Ferro et al., 2017). Noteworthy, Karakul sheep has a long breeding season, with the possibility of giving three births in two years (Aljubouri et al., 2020a). Recently, the Iranian Karakul sheep have been imported to Iraq and raised alongside Awassi in the same breeding stations. Hence, it is necessary to compare the metabolic performance of both breeds using two of the most important metabolic hormones as indicators for comparison. Considering the importance of metabolic $\mathrm{T} 4$ and $\mathrm{GH}$ hormones in improving the live body weight performance of sheep, the study aims to investigate the association between both hormones with the main growth traits of Awassi and Karakul sheep.

\section{Materials \& Methods}

\section{Animal resources}

This study was conducted in the animal field of the Al-Kafeel Company (the Abbasid shrine, Barakat Aba Al-Fadl station, Karbala province) during the period extended from 1/11/2019 to $30 / 5 / 2020$. This station was situated at a longitude of $32.6027^{\circ} \mathrm{N}$, the latitude of $44.0197^{\circ} \mathrm{E}$, and $32 \mathrm{~m}$ above mean sea level. The experiments were included a total of 60 lambs, 28 (13 males and 15 females) lambs of Awassi sheep, and 32 (18 males and 14 females) lambs from the Iranian Karakul. Each included lamb was numbered during the birth months (November and December, 2019). Ewes were isolated with their newborns after birth in places designated for the experiments. All lambs were placed during the first three days under observation to ensure that they suckled and consumed colostrum. After being numbered, the body measurements were conducted following the protocol described by (Everett-Hincks \& Dodds 2008). Then, the weights of lambs were measured at three 


\section{Aljubouri et al, / Basrah J. Agric. Sci., 34(2): 107-117, 2021}

periods of age (birth, weaning, and six months of age) for both analyzed breeds according to the protocol of (Zhao et al., 2017).

\section{Feeding lambs}

The newborn lambs were left with their dams during the first two weeks of age. In the third week, the dams went out to graze and the newborn lambs remained in the sheds and merged with the mothers after their return from grazing until the next day during the first month. At the beginning of the second month, the lambs remained inside the sheds and were given $150 \mathrm{~g}$ of a concentrated diet with dams' milk consumed before and after their return from grazing. In the period extended from the third month of age until weaning (Three months years old), lambs are given a 200 g.Day-1 concentrate diet. This amount of diet had gradually increased with the increase of weight of lambs. Add to that, lambs were fed dams' milk until weaning. In the period between the fourth month to the sixth month of age, lambs were given a fattening concentrate (barley 50\%, bran $30 \%$, crushed corn $10 \%$ soybean cake $8 \%$, salt $1 \%$, premix vitamins $1 \%$ ) at $2.5 \%$ of body weight and given as $500 \mathrm{~g}$ per lamb per day.

\section{Blood collection}

The blood samples were collected from the jugular vein of the lambs by a sterile medical syringe and placed in gel-containing test tubes ( $4 \mathrm{ml}$ capacity). The serum was separated by using a clinical centrifuge at $3461 \mathrm{rpm}$ for 6 minutes (EBA 20, Hettich, Germany). Blood samples were collected at the birth, weaning, and six months of age for both investigated breeds. Serum samples were kept frozen at a temperature of $-20^{\circ} \mathrm{C}$ in sealed microcentrifuge tubes (of $1.5 \mathrm{ml}$ capacity) until the thyroxine (T4) and growth hormone (GH) being assessed.

\section{Hormonal assays}

Both hormones were measured using the enzyme-linked immunosorbent assay (ELISA) kit. All reagents and samples were brought to room temperature, $30 \mathrm{~min}$ before starting the assay procedure. The absorbance of hormones was measured at $450 \mathrm{~nm}$ using a microplate reader. Concentrations were presented as nmol. $\mathrm{L}^{-1}$ for T4 and $\mathrm{ng} / \mathrm{ml}$ for GH. A standard curve was generated for each hormone measured, and samples were interloped according to the manufacturer's instructions.

\section{Statistical analysis}

Statistical Analysis System -SAS (2012) was used in data analysis to study the effect of different factors on the studied traits according to a complete randomized design (CRD). The significant differences between the averages were compared with the Duncan (1955) polynomial test. The following mathematical model was used in the study:

Yijk $=\mu+B i+S j+E i j k$

Where; $Y_{i j k}$ is the phenotypic value of the traits, $\mu$ is the overall mean, $B_{i}$ is the fixed effect of the breed ( $i=$ Awassi, Karakul), $S j$ is the fixed effect of the sex (Male, Female) and $E_{i j k}$ is the random residual effect of each observation. $p$ values of less than 0.05 were considered statistically significant for all comparisons.

\section{Results \& Discussions}

\section{T4 and GH variables}

Table (1) showed a highly significant effect ( $p$ $<0.01)$ for the level of T4 at birth $(6.847,5.241$ nmol. $\mathrm{L}^{-1}$ ) and weaning (4.500, $\left.3.857 \mathrm{nmol} . \mathrm{L}^{-1}\right)$ of the Karakul breed as compared with the 


\section{Aljubouri et al, / Basrah J. Agric. Sci., 34(2): 107-117, 2021}

Awassi breed respectively. The results showed that T4 concentrations of Karakul sheep (3.608 nmol. $\mathrm{L}^{-1}$ ) did not exhibit a higher level of statistical significance over the Awassi sheep (3.230 nmol. $\left.\mathrm{L}^{-1}\right)$ at the age of six months. GH showed a significant $(p<0.001)$ superiority at the weaning age of Karakul $\left.\left(0.647, \text { ng. }^{-1}\right)^{-1}\right)$ as compared with Awassi breed, it reached (0.579 ng. $\mathrm{ml}^{-1}$ ), while, its effect was not significant at birth and the age of six months.

Table (1): The levels of T4 and GH in Karakul and Awassi sheep in three periods of age (Mean \pm SE).

\begin{tabular}{|c|c|c|c|c|}
\hline Variable & Breed & $\mathbf{N}$ & Mean \pm Std. Error & $p$-value \\
\hline \multirow[t]{2}{*}{ T4 at birth (nmol. $\left.\mathrm{L}^{-1}\right)$} & Karakul & 28 & $6.847^{\mathrm{a}} \pm 0.343$ & \multirow[t]{2}{*}{0.0001} \\
\hline & Awassi & 32 & $5.241^{\mathrm{b}} \pm 0.184$ & \\
\hline \multirow[t]{2}{*}{$\mathrm{T} 4$ at weaning $\left(\mathrm{nmol} . \mathrm{L}^{-1}\right)$} & Karakul & 28 & $4.500^{\mathrm{a}} \pm 0.163$ & \multirow[t]{2}{*}{0.0161} \\
\hline & Awassi & 32 & $3.857^{\mathrm{b}} \pm 0.195$ & \\
\hline \multirow[t]{2}{*}{ T4 at six months (nmol. $\mathrm{L}^{-1}$ ) } & Karakul & 28 & $3.608^{a} \pm 0.201$ & \multirow[t]{2}{*}{0.1143} \\
\hline & Awassi & 32 & $3.230^{\mathrm{a}} \pm 0.132$ & \\
\hline \multirow[t]{2}{*}{$\mathrm{GH}$ at birth $\left(\mathrm{nmol} \cdot \mathrm{L}^{-1}\right)$} & Karakul & 28 & $0.642^{\mathrm{a}} \pm 0.037$ & \multirow[t]{2}{*}{0.1189} \\
\hline & Awassi & 32 & $0.719^{a} \pm 0.033$ & \\
\hline \multirow[t]{2}{*}{ GH at weaning $\left(\mathrm{nmol} . \mathrm{L}^{-1}\right)$} & Karakul & 28 & $0.642^{\mathrm{a}} \pm 0.020$ & \multirow[t]{2}{*}{0.0550} \\
\hline & Awassi & 32 & $0.591^{\mathrm{b}} \pm 0.017$ & \\
\hline \multirow[t]{2}{*}{ GH at six month $\left(\mathrm{nmol} . \mathrm{L}^{-1}\right)$} & Karakul & 28 & $0.903^{a} \pm 0.108$ & \multirow[t]{2}{*}{0.7290} \\
\hline & Awassi & 32 & $0.853^{\mathrm{a}} \pm 0.097$ & \\
\hline \multirow[t]{2}{*}{ Birth weight } & Karakul & 28 & $4.328^{\mathrm{a}} \pm 0.135$ & \multirow[t]{2}{*}{0.0096} \\
\hline & Awassi & 32 & $3.907^{b} \pm 0.086$ & \\
\hline \multirow[t]{2}{*}{ Weaning weight } & Karakul & 28 & $24.321^{\mathrm{a}} \pm 1.006$ & \multirow[t]{2}{*}{0.0024} \\
\hline & Awassi & 32 & $20.687^{b} \pm 0.608$ & \\
\hline \multirow[t]{2}{*}{ six months' weight } & Karakul & 28 & $34.357^{\mathrm{a}} \pm 1.066$ & \multirow[t]{2}{*}{0.0001} \\
\hline & Awassi & 32 & $28.843^{b} \pm 0.794$ & \\
\hline
\end{tabular}

Values with different superscript letters within the same column differ significantly 


\section{Aljubouri et al, / Basrah J. Agric. Sci., 34(2): 107-117, 2021}

On the other hand, lambs of the Karakul breed significantly $(p<0.01)$ exceeded the Awassi breed in live weights at birth (4.328 and $3.907 \mathrm{~kg}$ ), weaning (24.321 and $20.687 \mathrm{~kg}$ ), and six months of age ( 34.357 and $28.843 \mathrm{~kg}$ ), respectively. The present study is in agreement with other reports that indicated the presence of a proportional association of $\mathrm{T} 4$ with live body weight in sheep (Blum et al., 1980; Caldeira et al., 2007; Koluman \& Daskiran, 2011). Furthermore, T4 has represented a good indicator for the nutritional level due to its possible association with the status of feed intake in sheep (Abdel-Fattah et al., 2013). This kind of association has been confirmed, since T4 showed a high correlation with live body weights in Karakul sheep at the first six months of age (Mirhoseini et al., 2015). Furthermore, our study has also complied with other investigations performed on the Awassi sheep, in which significant differences in live body weights were identified in the same analyzed time intervals (Singh et al., 2018). Our results are also consistent with Carlos et al. (2015), who referred to the elevation for T4 in Morada Nova sheep in Brazil. However, our results did not consistent with other studies that did not show any significant differences in T4 concentrations among various Asian sheep breeds (Sharma et al., 2016). In contrast to our study, it was shown that there were no significant differences between the weights of the Karakul and Awassi breeds at the age of 3, 6 , and 9 months, which may be due to several genetic and non-genetic factors (Aljubouri et al., 2020c). Nevertheless, the presence of a higher level of T4 concentrations in the Karakul (having higher body weights) in comparison with Awassi sheep (having lower body weights) may indicate a positive association between $\mathrm{T} 4$ and body weight in these breeds. For this reason, it is rational to say that the elevated $\mathrm{T} 4$ has been correlated with the increased live body weight indices in the investigated populations.

\section{Association of T4 and GH levels with sex}

It was found that the concentrations of $\mathrm{T} 4$ were not significant between both investigated breeds in both sexes at birth $\left(6.011\right.$ nmol.L ${ }^{-1}$ for Karakul, $5.973 \mathrm{nmol}^{-\mathrm{L}^{-1}}$ for Awassi), and at six months (3.548 nmol.L ${ }^{-1}$ for Karakul, 3.282 $\mathrm{nmol} / \mathrm{L}$ for Awassi). Whereas, the concentration of T4 showed significant differences $(p<0.01)$ at weaning age, in which the male lambs (4.500 nmol.L $\left.\mathrm{L}^{-1}\right)$ exceeded the female lambs (3.856 nmol. $\left.\mathrm{L}^{-1}\right)$ for both breeds. In contrast to $\mathrm{T} 4$, there were no significant differences in the lambs' sex in the concentrations of GH in all three periods of age (Table 2).

Results showed that the male lambs significant $(p<0.01)$ exceeded female lambs in weights at weaning (23.964 and $21,000 \mathrm{~kg}$ ) and the age of six months $(p<0.05)$ (32.992 and $29.125 \mathrm{~kg}$ ) respectively. However, the sexual differences in live body weights did not reach the level of significance at birth for both breeds. Several reports have indicated the superiority of males over females in live body weights in the Iraqi Karadi sheep (Hama Khan et al., 2019), and Turkish Karakul sheep (Halil \& Özbeyaz, 2020). Furthermore, it has also been shown that the male lambs of the Iranian Baluchi breed have outperformed the female lambs in weights from birth to the age of six months (Binabaj et al., 2021). 
Aljubouri et al, / Basrah J. Agric. Sci., 34(2): 107-117, 2021

Table (2): The interaction of sex of lambs, level of T4 and GH, and live body weights of both Awassi and Karakul breeds (Mean \pm SE).

\begin{tabular}{|c|c|c|c|c|}
\hline Variable & sex & $\mathbf{N}$ & Mean \pm Standard Error & $p$-value \\
\hline \multirow[t]{2}{*}{ T4 at birth (nmol.L $\left.\mathrm{L}^{-1}\right)$} & M & 29 & $6.011^{\mathrm{a}} \pm 0.288$ & 0.9296 \\
\hline & $\mathrm{F}$ & 31 & $5.973^{\mathrm{a}} \pm 0.314$ & \\
\hline \multirow[t]{2}{*}{ T4 at weaning (nmol. $\left.\mathrm{L}^{-1}\right)$} & M & 29 & $4.500^{\mathrm{a}} \pm 0.220$ & 0.0160 \\
\hline & $\mathrm{F}$ & 31 & $3.856^{\mathrm{b}} \pm 0.147$ & \\
\hline \multirow[t]{2}{*}{ T4 at 6 months $\left(\right.$ nmol. $\left.\mathrm{L}^{-1}\right)$} & M & 29 & $3.548^{\mathrm{a}} \pm 0.174$ & 0.2687 \\
\hline & $\mathrm{F}$ & 31 & $3.282^{\mathrm{a}} \pm 0.162$ & \\
\hline \multirow[t]{2}{*}{ GH at birth (nmol.L $\left.{ }^{-1}\right)$} & M & 29 & $0.707^{\mathrm{a}} \pm 0.037$ & 0.2394 \\
\hline & $\mathrm{F}$ & 31 & $0.669^{\mathrm{a}} \pm 0.034$ & \\
\hline \multirow[t]{2}{*}{$\mathrm{GH}$ at weaning $\left(\mathrm{nmol} . \mathrm{L}^{-1}\right)$} & M & 29 & $0.607^{\mathrm{a}} \pm 0.018$ & 0.7346 \\
\hline & $\mathrm{F}$ & 31 & $0.615^{\mathrm{a}} \pm 0.018$ & \\
\hline \multirow[t]{2}{*}{ GH at 6 month (nmol.L $\left.\mathrm{L}^{-1}\right)$} & M & 29 & $0.851^{\mathrm{a}} \pm 0.097$ & 0.4674 \\
\hline & $\mathrm{F}$ & 31 & $0.903^{\mathrm{a}} \pm 0.108$ & \\
\hline \multirow[t]{2}{*}{ Birth weight } & M & 29 & $4.230^{\mathrm{a}} \pm 0.129$ & 0.1535 \\
\hline & $\mathrm{F}$ & 31 & $3.993^{\mathrm{a}} \pm 0.102$ & \\
\hline \multirow[t]{2}{*}{ Weaning weight } & M & 29 & $23.964^{\mathrm{a}} \pm 0.97$ & 0.0145 \\
\hline & $\mathrm{F}$ & 31 & $21.00^{\mathrm{b}} \pm 0.705$ & \\
\hline \multirow[t]{2}{*}{ six months' weight } & M & 29 & $32.99^{\mathrm{a}} \pm 1.32$ & 0.0051 \\
\hline & $\mathrm{F}$ & 31 & $29.125^{\mathrm{b}} \pm 0.72$ & \\
\hline
\end{tabular}

Values with different superscript letters within the same column differ significantly.

However, no significant effect of the sex of the lambs was reported on the live body weights and weight gain in the Syrian Awassi sheep (Aljubouri et al., 2020b). The difference in the live body weight measurements between males and females with the progress of age may be due to the increasing differences in the endocrine system and the role of the male hormones, which are essential for building bones and muscle growth (Karsenty \& Olson, 2016). These key metabolic roles can be 


\section{Aljubouri et al, / Basrah J. Agric. Sci., 34(2): 107-117, 2021}

attributed as estrogen works to inhibit the longitudinal growth of body bones while androgen acts as a structural hormone that promotes growth and speeds up the growth of bones (Ekambaram et al., 2013; Karmakar et al., 2018). This was probably owing to a greater activity of the pituitary gland in males promoted by sexual hormones (Kumar et al., 2014). However, our results are not in agreement with Eshratkhah et al. (2010) who showed the absence of any noticeable difference of $\mathrm{T} 4$ values between both sexes of Moghani sheep.

\section{Correlation between levels of metabolic hormones and growth traits}

The results of the study indicate a highly significant positive correlation $(p<0.01)$ between the T4 concentration at birth with the weight of lambs at weaning $(r=0.27280, P=$ $0.0350)$, and at six months of age $(r=0.33862$, $\mathrm{P}=0.0081)$. A highly significant positive correlation $(p<0.01)$ was also observed between the level of T4 at weaning and the weight of the lambs at weaning $(r=0.44245, \mathrm{P}$ $=0.0004)$ and at six months of age $(r=$ $0.36534, \mathrm{P}=0.0041)$. However, no noticeable correlation was reported between $\mathrm{GH}$ concentration and growth characteristics in both breeds (Table 3 ).

A highly significant $(p<0.01)$ positive correlation between the weight of the lambs at birth and weaning $(\mathrm{r}=0.32369, \mathrm{P}=0.0116)$ was observed. Another positive correlation between the weight of the lambs at birth and six months of age $(\mathrm{r}=0.21653, \mathrm{P}=0.0966)$ was also observed. However, this correlation was not reached a significant level. Additionally, a highly positive correlation $(p<0.01)$ was recorded between the weight of the lambs at weaning and the age of six months ( $\mathrm{r}=$ $0.81686, \mathrm{P}=0.0001)$. The results indicated a positive and significant correlation $(p<0.01)$ between the concentration of $\mathrm{T} 4$ and live body weight at birth, weaning, and six months of age. The positive correlation was highly significant $(p<0.01)$ with live body weight for lambs at birth, weaning, and six months of age. This study is consistent with a study conducted on sheep that indicated a proportional increase in the level of T4 and live body weight with age (Carlos et al., 2015).

This observation can be explained by the rapid requirements of the growing lambs to elevate T4 values in the blood and then binds to its receptors on the surface of the muscle cells to achieve better effectiveness at work and better biological functions (Haddad et al., 2001). Thyroid hormones show pleiotropic effects on osteoblast function and differentiation, early pregnancy, and in a wide range of activities in metabolism, growth, and development (Candelotti et al., 2015). This is also consistent with the studies that reported a positive correlation between birth weights with subsequent weaning and six-month weights in Madras red sheep, Carole $\times$ Malpura sheep, Harnali sheep, and Egyptian Barki sheep (Gowane et al., 2011; Ganesan et al., 2013; Lalit et al., 2016; Abd El Tawab et al., 2020). Furthermore, it was shown that Akkaraman sheep recorded a tight correlation with $\mathrm{T} 4$ level, growth, and wool shearing capacity (Pehlivan et al., 2020). In contrast with T4 results, our study refuted any correlation between the concentration of $\mathrm{GH}$ and the age of investigated sheep at birth, weaning, and six months' age. These results are also supported in Norduz Sheep (Karakuş et al., 2017). 
Aljubouri et al, / Basrah J. Agric. Sci., 34(2): 107-117, 2021

Table (3): Correlation between the level of metabolic hormones and the live body weights of Awassi and Karakul breeds.

\begin{tabular}{|c|c|c|c|c|}
\hline Variable & r/p-value & birth & weaning & Six months weight \\
\hline & & weight & weight & \\
\hline \multirow[t]{2}{*}{ T4 at birth (nmol.L $\left.{ }^{-1}\right)$} & $\mathrm{r}$ & 0.125 & 0.272 & 0.338 \\
\hline & $p$-value & 0.338 & 0.035 & 0.008 \\
\hline \multirow[t]{2}{*}{ T4 at weaning (nmol.L $\left.{ }^{-1}\right)$} & $\mathrm{r}$ & -0.044 & 0.442 & 0.365 \\
\hline & $p$-value & 0.736 & 0.0004 & 0.004 \\
\hline \multirow{2}{*}{$\begin{array}{l}\text { T4 at six months } \\
\left(\mathrm{nmol} . \mathrm{L}^{-1}\right)\end{array}$} & $\mathrm{r}$ & 0.051 & 0.452 & 0.419 \\
\hline & $p$-value & 0.696 & 0.0003 & 0.001 \\
\hline \multirow[t]{2}{*}{ GH at birth (nmol.L $\left.{ }^{-1}\right)$} & $\mathrm{r}$ & -0.064 & -0.203 & -0.140 \\
\hline & $p$-value & 0.625 & 0.119 & 0.283 \\
\hline \multirow[t]{2}{*}{ GH at weaning $\left(\mathrm{nmol} . \mathrm{L}^{-1}\right)$} & $\mathrm{r}$ & 0.131 & -0.015 & 0.077 \\
\hline & $p$-value & 0.317 & 0.909 & 0.557 \\
\hline \multirow{2}{*}{$\begin{array}{l}\text { GH at } 6 \text { months } \\
\left.\left(\mathrm{nmol}^{-1}\right)^{-1}\right)\end{array}$} & $\mathrm{r}$ & -0.006 & -0.088 & -0.047 \\
\hline & $p$-value & 0.961 & 0.501 & 0.717 \\
\hline \multirow[t]{2}{*}{ Birth weight } & $\mathrm{r}$ & - & 0.323 & 0.216 \\
\hline & $p$-value & & 0.012 & 0.097 \\
\hline \multirow[t]{2}{*}{ Weaning weight } & $\mathrm{r}$ & - & - & 0.816 \\
\hline & $p$-value & - & - & $<.0001$ \\
\hline
\end{tabular}

\section{Conclusions}

The high correlations between the elevated T4 values with the body weight gain in three different age periods indicate the possibility to employ this tight correlation in the breeding programs for early selection of lambs to improve lambs' weights at marketing age.

\section{Conflict of interest}

Authors declare that they have no conflict of interest.

\section{Ethical approval}

The experimental procedures of this study were approved by the Animal Committee of AlQasim Green University, Babil, Iraq.

\section{Acknowledgements}

This paper was partially supported by Al-Qasim Green University, Iraq.

\section{ORCID}

T. R. S. Aljubouri: 0000-0002-6853-3335

F. M. Al-Khafaji: 0000-0002-1223-6366

M. B. S. Al-Shuhaib: 0000-0002-6458-2068

\section{References}

Abdel-Fattah, M., Hashem, A., Shaker, Y., Ellamei, A., \& Amer, H. (2013). Effect of weaning age on productive performance and some plasma biochemical parameters of Barki lambs in Siwa Oasis, Egypt. Global Veterinaria, 10, 189-202. http://www.idosi.org/gv/gv10(2)13/14.pdf 


\section{Aljubouri et al, / Basrah J. Agric. Sci., 34(2): 107-117, 2021}

Ajam, I. K., Al-Jubouri, T. R., \& Ghayyib, Q. H. (2019). TGF-B super family correlation with the fertility of Iraqi Awassi Ewes. Basrah Journal of Agricultural Sciences, $\quad 32, \quad 26-32$. https://doi.org/10.37077/25200860.2019.137

Aljubouri, T. R., \& Al-Shuhaib, M. B. S. (2021). Genotyping of mitochondrial D-loop sequences in three breeds of sheep. Biologia, 76, 203-211. https://doi.org/10.2478/s11756-020-00543-6

Aljubouri, T. R., Hassan, A. F., \& Al-Shuhaib, M. B. S. (2020a). Exhibition of different hormonal regulations in Awassi and Karakul breeds at sexual maturity. Plant Archives, 20, 5937-5940. http://www.plantarchives.org/20-2/59375940\%20(6885).pdf

Aljubouri, T. R., Al-Shuhaib, M. B. S., \& Javadmaneshb, A. (2020c). HMGA2 gene polymorphisms and their effects on main growth traits indices in Awassi and Karakul sheep. Agriculture and Natural Resources, 54 , 587-594. https://doi.org/10.34044/j.anres.2020.54.6.03

Aljubouri, T. R., Hassan, A. F., Al-Shuhaib, M. B. S., \& Mahyari, S. A. (2020b). Association of GnRHI gene with growth traits in two breeds of sheep. Agricultural Research, 10, 285-293. https://doi.org/10.1007/s40003-020-00501-3

Almahdawi, M. K., \& Altalib, A. A. (2020). Impact of using dried bread residue as substitution of energy source for cereals on milk production and its ingredients of Awassi ewes. Eurasian Journal of Biosciences, 14, 407-416.

Al-Shuhaib, M. B. S., Al-Thuwaini, T. M., Fadhil, I. A., \& Aljubouri, T. R. (2019). GHRL gene-based genotyping of ovine and caprine breeds reveals highly polymorphic intronic sequences in Awassi sheep with several RNA motifs. Journal of Genetic Engineering and Biotechnology, 17, 1.8. https://doi.org/10.1186/s43141-019-0004-5

Al-Thuwaini, T.M., Al-Shuhaib, M.B.S., Lepretre, F. \& Mahdi, Z.A. (2020). Co-inherited novel SNPs of the LIPE gene associated with increased carcass dressing and decreased fat-tail weight in Awassi breed. Tropical Animal Health and Production, 52, 3631-3638. https://doi.org/10.1007/s11250-02002400-9.
Binabaj, F. B., Farhangfar, S. H., \& Jafari, M. (2021). Inbreeding affected differently on observations distribution of a growth trait in Iranian Baluchi sheep. Asian-Australasian Journal of Animal Sciences, $\quad 34, \quad 506-515$. https://doi.org/10.5713/ajas.19.0642

Blum, J., Gingins, M., Vitins, P., \& Bickel, H. (1980). Thyroid hormone levels related to energy and nitrogen balance during weight loss and regain in adult sheep. European Journal of Endocrinology, 93, 440-447. https://doi.org/10.1530/acta.0.0930440

Caldeira, R., Belo, A., Santos, C., Vazques, M., \& Portugal, A. (2007). The effect of body condition score on blood metabolites and hormonal profiles in ewes. Small Ruminant Research, 68, 233-241. https://doi.org/10.1016/j.smallrumres.2005.08.027

Candelotti, E., De Vito, P., G Ahmed, R., Luly, P., J Davis, P., Z Pedersen, J., Yun, H., \& Incerpi, S. (2015). Thyroid hormones crosstalk with growth factors: Old facts and new hypotheses. Immunology, Endocrine \& Metabolic Agents; in Medicinal Chemistry (Formerly Current Medicinal ChemistryImmunology, Endocrine and Metabolic Agents), 15, 71-85.

Carlos, M., Leite, J., Chaves, D., Vale, A., Facanha, D., Melo, M., \& Soto-Blanco, B. (2015). Blood parameters in the Morada Nova sheep: influence of age, sex and body condition score. The Journal of Animal \& Plant Sciences, 25, 950-955.

Duncan, D. B. (1955). Multiple Rang and Multiple Ftest. Biometrics. 11, 4-42.

Ekambaram, B., Alexander, G., \& Kalyana Chakravarthi, M. (2013). Performance of Nellore sheep (Jodipi) under farm conditions. Indian Veterinary Journal, 90(12): 35-37.

Eshratkhah, B., Sadaghian, M., Eshratkhah, S., Pourrabbi, S., \& Najafian, K. (2010). Relationship between the blood thyroid hormones and lipid profile in Moghani sheep; influence of age and sex. Comparative clinical Pathology, 19, 15-20. https://doi.org/10.1007/s00580-009-0904-x

Everett-Hincks, J., \& Dodds, K. (2008). Management of maternal-offspring behavior to improve lamb survival in easy care sheep systems. Journal of 


\section{Aljubouri et al, / Basrah J. Agric. Sci., 34(2): 107-117, 2021}

Animal Science, 86, E259-E270. https://doi.org/10.2527/jas.2007-0503

Ferro, M., Tedeschi, L. O., \& Atzori, A. (2017). The comparison of the lactation and milk yield and composition of selected breeds of sheep and goats. Translational Animal Science, 1, 498-506. https://doi.org/10.2527/tas2017.0056

Ganesan, R., Dhanavanthan, P., Balasubramanyam, D., \& Kumarasamy, P. (2013). Estimates of genetic parameters of growth traits in Madras Red sheep. IOSR Journal of Agriculture and Veterinary Sciences, 3, 69-73.

Gowane, G. R., Chopra, A., Prince, L., Mishra, A., \& Arora, A. (2011). Genetic analysis for growth traits of prolific Garolex Malpura (GM) sheep. Tropical Animal Health and Production, 43, 299-303. https://doi.org/10.1007/s11250-010-9718-8

Haddad, S., Nasr, R., \& Muwalla, M. (2001). Optimum dietary crude protein level for finishing Awassi lambs. Small Ruminant Research, 39, 41-46. https://doi.org/10.1016/S0921-4488(00)00172-3

Halil, E., \& Özbeyaz, C. (2020). Investigating various performance traits of Karakul sheep. Ankara Üniversitesi Veteriner Fakültesi Dergisi, 67, 113120. https://doi.org/10.33988/auvfd.491960

Hama Khan, K., Al-Barzinji, Y., \& Maarof, N. (2019). A study of body weight and milk traits of Karadi Ewes-Sulaimani Governorate, Iraq. Applied Ecology and Environmental Research, 17, 1402514038 . http://dx.doi.org/10.15666/aeer/1706_1402514038

Imran, F. S., Al-Thuwaini, T. M., Al-Shuhaib, M. B. S., \& Lepretre, F. (2021). A novel missense single nucleotide polymorphism in the GREM1 gene is highly associated with higher reproductive traits in Awassi sheep. Biochemical Genetics, 59, 422-436. https://doi.org/10.1007/s10528-020-10006-X

Jawasreh, K. I., Al-Amareen, A. H., \& Aad, P. Y. (2019). Relationships between Hha1 calpastatin Gene Polymorph- ism, growth Performance, and meat characteristics of Awassi sheep. Animals, 9, 667. https://doi.org/10.3390/ani9090667

Karmakar, P., Behera, R., \& Mandal, A. (2018). Growth performance and effect of non-genetic factors affecting growth traits in Garole sheep. Indian Journal of Animal Sciences, 88, 117-119.

Karakuş, K., Comba, B., Taş, A., Sancak, T., Comba, A., Sarıpınar Aksu, D., \& Tariq, M. M. (2017). The effect of chemical and surgical castration on the live weight gain and some hormones of male Norduz sheep. Pakistan Journal of Zoology, 49, 1835-1840. https://hdl.handle.net/11491/167

Karsenty, G., \& Olson, E. N. (2016). Bone and muscle endocrine functions: unexpected paradigms of interorgan communication. Cell, 164(6), 1248-56. https://doi.org/10.1016/j.cell.2016.02.043

Koluman, N., \& Daskiran, I. (2011). Effects of ventilation of the sheep house on heat stress, growth and thyroid hormones of lambs. Tropical Animal Health and Production, 43, 1123-1127. https://doi.org/10.1007/s11250-011-9811-7

Kumar, A., Shekhar, S., \& Dhole, B. (2014). Thyroid and male reproduction. Indian Journal of Endocrinology \& Metabolism, 18, 23-31. https://doi.org/10.4103/2230-8210.126523

Lalit, Z., Dalal, D., Dahiya, S., Patil, C., \& Dahiya, R. (2016). Genetic analysis of growth traits in Harnali sheep. Veterinary World, 9, 128. https:// doi: 10.14202/vetworld.2016.128-132

Lopez-Rodriguez, M. F., Cymbaluk, N., Epp, T., Laarveld, B., Recalde, E. C. S., Simko, E., \& Card, C. (2020). Effects of the glucosinolate sinigrin in combination with a noniodine supplemented diet on serum iodine and thyroid hormone concentrations in nonpregnant mares. Journal of Equine Veterinary Science, $91, \quad 103110$. https://doi.org/10.1016/j.jevs.2020.103110

Mirhoseini, S. Z., Zare, J., Hossein-Zadeh, N. G., Khanzadeh, H., Seidavi, A., Laudadio, V., Dario, C., Tufarelli, V., \& Selvaggi, M. (2015). Estimation of genetic parameters for body weight traits and pelt quality score in Iranian Karakul sheep. Small Ruminant Research, 132, 67-71. https://doi.org/10.1016/j.smallrumres.2015.10.012

Oberbauer, A. M. (2015). Developmental programming: the role of growth hormone. Journal of Animal Science and Biotechnology, 6, 1-7. https://doi.org/10.1186/s40104-015-0001-8 


\section{Aljubouri et al, / Basrah J. Agric. Sci., 34(2): 107-117, 2021}

Pehlivan, E., Kaliber, M., Konca, Y., \& Dellal, G. (2020). Effect of shearing on some physiological and hormonal parameters in Akkaraman sheep. Asian-Australasian Journal of Animal Sciences, 33, 848. https://doi.org/10.5713/ajas.19.0400

SAS, J. (2012). Statistical Analysis System, v. 10.0. 2. Cary, North Carolina. USA.

Sharma, N., Nehra, K., \& Gahlot, G. (2016). Genetic Evaluation of Karakul and Marwari Sheep in Arid Zone of Rajasthan: Body Weights. Veterinary Practitioner, 17, 265-267.

Singh, S. P., Dass, G., Natesan, R., Kushwah, Y., Sharma, N., \& Kumar, A. (2018). Endocrine and hematobiochemical profile of lambs raised in a semiarid region with different growth potentials during the postweaning period. Turkish Journal of Veterinary and Animal Sciences, 42, 120-129. https://doi.org/10.3906/vet-1709-38

Todini, L., Malfatti, A., Valbonesi, A., TrabalzaMarinucci, M., \& Debenedetti, A. (2007). Plasma total T3 and T4 concentrations in goats at different physiological stages, as affected by the energy intake. Small Ruminant Research, 68, 285-290. https://doi.org/10.1016/j.smallrumres.2005.11.018

Zhao, H., He, S., Zhu, Y., Cao, X., Luo, R., Cai, Y., Xu, H., \& Sun, X. (2017). A novel 29 bp insertion/deletion (indel) variant of the LHX3 gene and its influence on growth traits in four sheep breeds of various fecundity. Archiv fuer Tierzucht, 60, 79. https://doi.org/10.5194/aab-60-79-2017

\section{علاقة بعض هرمونات الأيض مع زبادة وزن الجسم الحي في ذكور واناث حملان الكاراكول والعواسي ثامر راضي صاحب الجبوري، فراس مهدي عبد الرضا الخفاجي ومحمد باقر صاحب الثهيّب}

$$
\text { قسم الإنتاج الحيواني، كلية الزراعة، جامعة القاسم الخضراء، العراق }
$$

المستخلص: تم اجراء هذه الدراسة في الحقل الحيواني لشركة الكفيل من نوفمبر - 2019 الى أيار - 2020 للتحري عن العلاقة المحتملة ما بين هرمون النمو والثايروكسين مع صفات النمو في اغنام العواسي والكاراكول. استخدم في الدراسة 60 حملاً, 28 (13 ذكر و15 أنثى) من سلالة الكاراكول و 32 (18 ذكر و14 أنثى) من سلالة العواسي. تم جمع عينات الدم عند الولادة والفطام وعند عمر ستة اشهر ، حُسب تركيزي كل من هرموني النمو والثايروكسين. بيّنت النتائج وجود مستويات أعلى للثايروكسين لحملان الكاراكول مقارنة بحملان العواسي عند الولادة وعند الفطام. أبدت الحملان العائدة لسلالة الكاراكول ارتفاعاً معنوياً في هرمون النمو مقارنة بحملان سلالة العواسي عند الفطام، بينما لم يتم ملاحظة أي فروقات معنوية بينهما عند الولادة وعند ستة أشهر من العمر • واشارت النتائج الى ارتفاع معدلات اوزان حملان الكاراكول مقارنة بالحملان العواسية في كل الفترات الزمنية المدروسة. تم ملاحظة علاقة معنوية موجبة عالية (0.01 > p) ما بين تركيز الثايروكسين ووزن الحملان في معظم الأوقات الزمنية المدروسة. بينما ، لـ تُظهر النتائج وجود علاقة بين هرمون النمو وصفات النمو التي تم قياسها في كلا الصنفين. ربما يكون ارتفاع مستوى الثايروكسين هو أحد الأسباب المسؤولة عن تفوق الكاراكول على العواسي في الاوزان الجسمية الحية. ويمكن أن تستخدم هذه العلاقة الكبيرة مابين

$$
\begin{aligned}
& \text { الثايروكسين وصفات النمو في الانتخاب المبكر للحملان لتحسين أوزان الأغنام عند التسويق. } \\
& \text { الكلمات المفتاحية: هرمون النمو، صفات النمو، الأغنام، هرمون الثايروكسين، تحسين الوزن. }
\end{aligned}
$$

